\title{
Amyloid $\beta$ Peptide Induces Apoptosis Through P2X7 Cell Death Receptor in Retinal Cells: Modulation by Marine Omega-3 Fatty Acid DHA and EPA
}

\author{
Anaïs Wakx ${ }^{1,5}$ - Mélody Dutot ${ }^{1,2,5}$ - France Massicot ${ }^{1,5}$. \\ Frédéric Mascarelli $^{3,5}$ - G. Astrid Limb ${ }^{4}$ Patrice Rat ${ }^{1,5}$
}

Received: 14 April 2015 / Accepted: 28 September 2015 /

Published online: 14 October 2015

(C) The Author(s) 2015. This article is published with open access at Springerlink.com

\begin{abstract}
Retinal Müller glial cells have already been implicated in age-related macular degeneration (AMD). AMD is characterized by accumulation of toxic amyloid- $\beta$ peptide $(A \beta)$; the question we raise is as follows: is $\mathrm{P} 2 \mathrm{X} 7$ receptor, known to play an important role in several degenerative diseases, involved in A $\beta$ toxicity on Müller cells? Retinal Müller glial cells were incubated with $\mathrm{A} \beta$ for $48 \mathrm{~h}$. Cell viability was assessed using the alamarBlue assay and cytotoxicity using the lactate dehydrogenase (LDH) release assay. P2X7 receptor expression was
\end{abstract}

\section{Patrice Rat}

patrice.rat@parisdescartes.fr

Anaïs Wakx

anais.wakx@free.fr

Mélody Dutot

melody.dutot@yslab.fr

France Massicot

france.massicot@parisdescartes.fr

Frédéric Mascarelli

Frederic.mascarelli@inserm.fr

G. Astrid Limb

g.limb@ucl.ac.uk

UMR CNRS 8638 - Chimie-Toxicologie Analytique et Cellulaire, Sorbonne Paris Cité, Faculté de Pharmacie, Université Paris Descartes, 4 avenue de l'Observatoire, 75006 Paris, France

2 Laboratoire Yslab, 2 rue Félix Le Dantec, 29000 Quimper, France

3 INSERM U 872-Physiopathologie des maladies oculaires: Innovations thérapeutiques, Centre de Recherches des Cordeliers, 15 Rue de l'Ecole de Médecine, 75006 Paris, France

4 Division of Ocular Biology and Therapeutics, UCL Institute of Ophthalmology and Moorfields Eye Hospital, 11 Bath Street, London EC1V 9EL, UK

5 Inserm U598, Physiopathologie des maladies oculaires, Innovations thérapeutiques, Centre de Recherches Biomédicales des Cordeliers, 75270 Paris Cedex 06, France 
highlighted by immunolabeling observed on confocal microscopy and its activation was evaluated by YO-PRO-1 assay. Hoechst 33342 was used to evaluate chromatin condensation, and caspases 8 and 3 activation was assessed using AMC assays. Lipid formulation rich in eicosapentaenoic acid (EPA) and docosahexaenoic acid (DHA) used in Age-Related Eye Disease Study 2 was incubated on cells for 15 min prior to $A \beta$ incubation. For the first time, we showed that $A \beta$ induced caspaseindependent apoptosis through $\mathrm{P} 2 \mathrm{X} 7$ receptor activation on our retinal model. DHA and EPA are polyunsaturated fatty acids recommended in food supplement to prevent AMD. We therefore modulated $\mathrm{A} \beta$ cytotoxicity using a lipid formulation rich in DHA and EPA to have a better understanding of the results observed in clinical studies. We showed that fish oil rich in EPA and DHA, in combination with a potent $\mathrm{P} 2 \mathrm{X} 7$ receptor antagonist, represents an efficient modulator of $\mathrm{A} \beta$ toxicity and that $\mathrm{P} 2 \mathrm{X} 7$ could be an interesting therapeutic target to prevent AMD.

Keywords Age-related macular degeneration $\cdot \mathrm{P} 2 \mathrm{X} 7$ receptor $\cdot$ Amyloid- $\beta$ peptide $\cdot$ Retinal cells $\cdot$ Apoptosis $\cdot$ DHA $\cdot$ EPA $\cdot$ Omega-3 fatty acid

\section{Introduction}

Age-related macular degeneration (AMD) is a progressive degeneration of the macula, the portion of the retina used for central vision. It is the leading cause of the irreversible loss of vision in those aged over 50 years in the Western industrialized world [1]. The United Nations estimates the number of people with AMD at 20-25 million worldwide [2]. As AMD progresses, it can develop into two distinct forms of late or advanced AMD: "dry" AMD (geographic atrophy, $90 \%$ ) and "wet" AMD (neovascular AMD, $10 \%$ ). Early stage of AMD is characterized by the formation of drusen that are deposits of extracellular material located underneath the retinal pigmented epithelium (RPE). Drusen provokes an inflammatory response and is associated with RPE atrophy. Photoreceptors overlying drusen die by apoptosis, whereas retinal Müller glial cells are activated. Under physiological conditions, Müller cells are responsible for maintaining its homeostasis, support neuronal activity, and participate in the induction, maintenance, and proper functioning of the blood-retinal barrier [3-5]. Alterations of Müller cells under pathological conditions can contribute to retinal degeneration [6-8]. Especially, Müller cell dysfunction leads to photoreceptor apoptosis and blood-retinal barrier breakdown $[9,10]$. There is no curative treatment against atrophic AMD, which affects $90 \%$ of AMD patients. Indeed, consumption of micronutrients, such as zinc, $\beta$-carotene, or vitamins, has been shown to prevent AMD progression. A study reviewing the role of dietary omega-3 long chain polyunsaturated fatty acid (PUFA) in the prevention of AMD reported a $38 \%$ reduced rate of progression to late AMD [11]. docosahexaenoic acid (DHA, C22:6 $\omega-3$ ) and its precursor eicosapentaenoic acid (EPA, C20:5 $\omega-3)$ are the major structural long chain PUFAs of the membrane of photoreceptors [12]. DHA is essential for the biogenesis and the function of photoreceptors [13]. Moreover, EPA and DHA have antioxidant, anti-inflammatory, antiapoptotic, and antiangiogenic roles in the retina $[14,15]$. PUFA content in the retina decreases with aging and it potentially induces a dysfunction of retinal cells. Participants who reported the highest levels of EPA consumption had a reduced likelihood of AMD progression [16]. Amyloid- $\beta$ (A $\beta)$ peptide is a key constituent of drusen [17-19]. It has been suggested that drusen could correspond to the transposition of senile plaques in Alzheimer's disease (AD). In the retina of mice models of $\mathrm{AD}$, an age-dependent $\mathrm{A} \beta$ accumulation has been detected, possibly resulting in neurodegeneration [20]. It has been found that oligomerized $A \beta$ 
is more toxic than is nonoligomerized $\mathrm{A} \beta$ in retinal cell cultures [21, 22]. Retinal toxicity seems to be associated with oxidative stress and pro-inflammatory response, but underlying mechanisms remain not clearly defined $[23,24]$. The purinergic receptor P2X7 is an ATPgated cationic channel expressed by virtually all types of cells $[25,26]$. P2X7 is involved in oxidative stress, cell death, and inflammatory processes, all of which have been linked to AMD [27, 28]. A recent genetic study has demonstrated that a haplotype containing a rare genetic variant of $\mathrm{P} 2 \mathrm{X} 7$ receptor is associated with increased susceptibility to AMD [29].Moreover, Notomi et al. recently proposed Brilliant Blue G (BBG), a selective P2X7 receptor antagonist, as a neuroprotective agent in retinal diseases [30]. The first aim of our study was to describe the P2X7-dependent cell death pathway induced by A $\beta$ on Müller cells. Our second aim was to modulate $\mathrm{A} \beta$ cytotoxicity using a lipid formulation rich in DHA and EPA, chosen for its ability to modulate toxic ocular stresses [31, 32].

\section{Methods}

\section{Reagents}

Reagents for cell culture were provided by Eurobio (Les Ulis, France), flasks and microplates from Corning (Schiphol-Rijk, The Netherlands) and chamber slides from Nunc Thermo Fisher Scientific (Rochester, NY, USA). Lipid formulation rich in DHA and EPA was provided by Yslab (Quimper, France). BBG, a specific P2X7 receptor inhibitor [33], was purchased from Bio-Rad (Richmond, CA, USA). Hoechst 33342, YO-PRO-1, TO-PRO-3, and secondary antibodies were purchased from Invitrogen (PoortGebouw, The Netherlands). A $\beta$ (Bachem, Weil am Rhein, Germany) was oligomerized as previously described [34]. Primary antibodies and IgG isotype control were provided from Santa Cruz Biotechnology (Heidelberg, Germany). All other chemicals, dyes, and kits were provided from Sigma-Aldrich (Saint Quentin Fallavier, France).

\section{Cell Culture}

The experiments were performed using the immortalized human Müller cell line MIO-M1 [35]. The MIO-M1 cell line was tested at IDEXX BioResearch (Columbia, MO, USA). The cell line was confirmed to be human and no evidence of cross-species contamination was found. The STR testing results reported for the cell line are as follows: amelogenin (X, Y), CSF1PO (13, 14), D13S317 (13), D16S539 (11, 12), D5S818 (12, 13), D7S820 (7, 9), TH01 $(6,9.3)$, TPOX $(6,9)$, and vWA $(15,19)$.

MIO-M1 were cultured using Dulbecco's Modified Eagle's medium, supplemented with $10 \%$ fetal bovine serum (FBS), $2 \mathrm{mM} \mathrm{L}$ glutamine, $50 \mathrm{IU} / \mathrm{mL}$ penicillin, and $50 \mathrm{IU} / \mathrm{mL}$ streptomycin, at $37{ }^{\circ} \mathrm{C}$ in a humidified atmosphere of $5 \% \mathrm{CO}_{2}$, as previously described [36]. Confluent cultures in flasks were removed by trypsin incubation, and then the cells were seeded into 96 -well (20,000 cells per well) or 24 -well (38,000 cells per well) culture microplates and kept at $37^{\circ} \mathrm{C}$ for $24 \mathrm{~h}$.

\section{Incubation Protocols}

Whenever the cells reached confluency, culture medium was removed and the cells were incubated with oligomerized $\mathrm{A} \beta 1-42$ at $25 \mu \mathrm{M}$ in $2.5 \% \mathrm{FBS}$ medium for $48 \mathrm{~h}$ at $37^{\circ} \mathrm{C}$. 
Excessive $A \beta$ was used to model AMD pathology. Twenty-five micromolars was the highest $A \beta$ concentration that did not induce any loss of cell viability in our model (data not shown).

Neat fish oil containing EPA and DHA (see composition in Table 1) was incubated for $15 \mathrm{~min}(100 \mu \mathrm{L} /$ well $)$ followed by $24 \mathrm{~h}$ in culture medium prior to $\mathrm{A} \beta$ incubation $[31,32,37]$. BBG (25 $\mu \mathrm{M}$, according to Kawahara [38]) was incubated with cells for 15 min prior to $A \beta$ incubation. BBG is a potent inhibitor of $\mathrm{P} 2 \mathrm{X} 7$ receptor since concentrations as low as $25 \mu \mathrm{M}$ are enough to inhibit receptor activation.

\section{Cell Viability (Necrosis Assessment): AlamarBlue Assay}

The alamarBlue ${ }^{\circledR}$ assay uses resazurin, a blue fluorogen probe, which is reduced to a red fluorescent compound (resorufin) by intracellular redox enzymes [39]. A solution of resazurin at $0.1 \mathrm{mg} / \mathrm{mL}$ was prepared in phosphate-buffered saline (PBS) then diluted to the eleventh well in culture medium supplemented with $2.5 \%$ FBS. The cells were exposed to resazurin solution for $6 \mathrm{~h}$ at $37^{\circ} \mathrm{C}$, then the fluorescence signal was read $(\lambda \mathrm{exc}=535 \mathrm{~nm}, \lambda \mathrm{em}=600 \mathrm{~nm}$, Safire; Tecan ${ }^{\circledR}$, Zurich, Switzerland).

\section{Cytotoxicity: LDH Release Assay}

The lactate dehydrogenase (LDH) assay measures membrane integrity as a function of the amount of cytoplasmic LDH released into the medium [40]. Briefly, cell supernatants were incubated with the LDH mixture containing NAD as LDH substrate and a tetrazolium dye (the mixture was prepared according to the manufacturer's instructions for Sigma kit TOX7) for $30 \mathrm{~min}$. Absorbance was detected at $490 \mathrm{~nm}$ (Safire; Tecan ${ }^{\circledR}$, Zurich, Switzerland).

\section{P2X7 Expression by Immunofluorescence Using Confocal Microscopy}

After seeding in chamber slides for $24 \mathrm{~h}$, the cells were fixed with $2 \%$ paraformaldehyde and $2 \mathrm{mM}$ calcium for $15 \mathrm{~min}$ at room temperature. The cells were then permeabilized with $0.2 \%$ Triton X-100 for $5 \mathrm{~min}$. First, the cells were incubated with primary antibody (rabbit anti-P2X7 at $5 \mu \mathrm{g} / \mathrm{mL}$ ) or rabbit IgG (isotype control) in PBS with $1 \%$ bovine serum albumin (BSA) for $1 \mathrm{~h}$, and second, the cells were incubated with secondary antibody (Alexa Fluor 488 anti-rabbit IgG) in PBS with $1 \%$ BSA for $1 \mathrm{~h}$ away from light. Third, nuclei were stained with TO-PRO-3 at $2 \mu \mathrm{g} / \mu \mathrm{L}$ for $10 \mathrm{~min}$. Slides were then observed under a Leica TCS SP2 confocal microscope (Leica Microsystems) equipped with a $40 \times$ oil immersion objective. Staining specificity was carefully checked by omitting the primary antibody.

Table 1 EPA and DHA (\%) and tocopherol $(\mathrm{mg} / \mathrm{g})$ composition of tested oil

\begin{tabular}{ll}
\hline & Fish YS-2636 \\
\hline C20:5 w3 EPA & 36 \\
C22:6 w3 DHA & 26 \\
Mixed tocopherol & 3.6
\end{tabular}


Confocal imaging was performed at IFR71-IMTCE Cellular and Molecular Imaging platform (Faculté de Pharmacie, Université Paris Descartes, Paris, France).

\section{P2X7 Activation: YO-PRO-1 Test}

YO-PRO-1, a fluorogenic probe, enters cells through $\mathrm{P} 2 \mathrm{X} 7$ receptor activation-induced pores and emits fluorescence when it binds DNA [41]. A 2- $\mu \mathrm{M}$ YO-PRO-1 solution in PBS was distributed in wells, and the microplate was placed at room temperature away from light for $10 \mathrm{~min}[42-46]$. The fluorescence signal was then scanned $(\lambda \mathrm{exc}=491 \mathrm{~nm}, \lambda \mathrm{em}=509 \mathrm{~nm}$, Safire; Tecan ${ }^{\circledR}$, Zurich, Switzerland).

\section{Chromatin Condensation: Hoechst 33342 Assay}

Hoechst 33342 dye is used to detect chromatin condensation in cells simultaneously with propidium iodide [44]. Hoechst 33342 enters living and apoptotic cells whereas propidium iodide enters necrotic cells faster than Hoechst 33342. A solution of Hoechst 33342 at $10 \mathrm{mg} /$ $\mathrm{mL}$ and propidium iodide at $0.5 \mathrm{mg} / \mathrm{mL}$ was prepared in PBS. Cells were exposed for $30 \mathrm{~min}$ at $37^{\circ} \mathrm{C}$, then the fluorescence was read $\left(\lambda \mathrm{exc}=365 \mathrm{~nm}, \lambda \mathrm{em}=450 \mathrm{~nm}\right.$, Safire; Tecan ${ }^{\circledR}$, Zurich, Switzerland).

\section{Caspases 3 and 8 Activation: AMC Assays}

The caspases 3 and 8 fluorometric assays were realized following the procedure for fluorometric assay of caspases 3 and 8 activity in adherent cell lines of the CASP3F and CASP8F Sigma kits. Briefly, the cells were treated with lysis buffer and incubated on ice for $20 \mathrm{~min}$. Then, DEVD-AMC for caspase 3 detection or IETD-AMC for caspase 8 detection was added in each well. The samples were incubated in the dark at room temperature for $30 \mathrm{~min}$. Afterward, the fluorescence signal was read $\left(\lambda e x c=360 \mathrm{~nm}, \lambda e m=460 \mathrm{~nm}\right.$, Safire; Tecan ${ }^{\circledR}$, Zurich, Switzerland).

\section{Results Exploitation and Statistical Analysis}

All data for microtitration were obtained in fluorescence or absorbance units and expressed as a percentage of the negative control (culture medium). Each point was tested in three different wells, and experiments were reproduced in triplicate. Data are expressed as means \pm standard deviation. The mean values for each test were analyzed by one-way ANOVA followed by the Dunnett test (SigmaStat 2.0; Chicago, Illinois, USA), and the level of significance was fixed at 0.05.

\section{Results}

\section{Cell Viability in A $\beta$-Incubated MIO-M1 Cells}

First, we investigated cell viability in A $\beta$-incubated MIO-M1 cells. A $\beta$ at $25 \mu \mathrm{M}$ did not induce any significant decrease in cell viability according to the alamarBlue assay (Fig. 1a). The LDH activity assay showed no significant change in the plasma membrane integrity which was detected in A $\beta$-incubated MIO-M1 in comparison to negative control (Fig. 1b). 
Fig. 1 Cell viability and cytotoxicity assessment after incubation of $25 \mu \mathrm{M} \mathrm{A} \beta$ for $48 \mathrm{~h}$. a Cell viability was assessed using global redox potential. b Necrosis was assessed using extracellular LDH dosage after $\mathrm{A} \beta$ incubation for $48 \mathrm{~h}$ in MIO-M1 retinal Müller cells

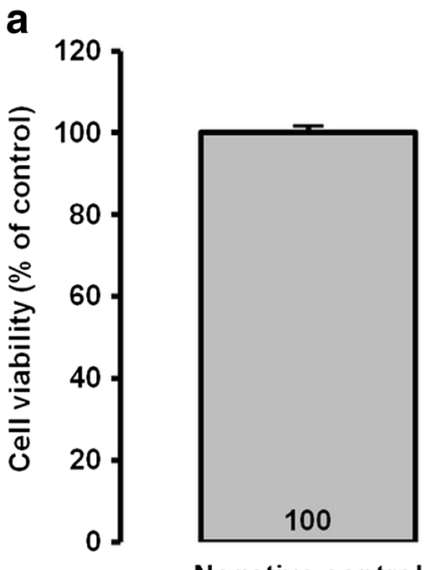

Negative control

b

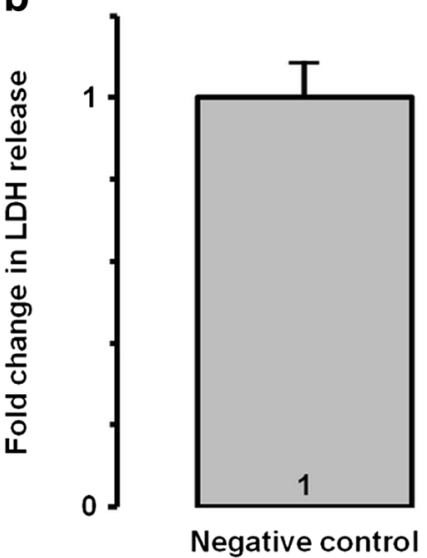

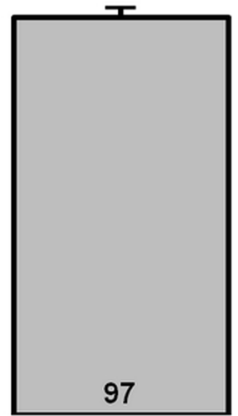

$A \beta 25 \mu \mathrm{M}$

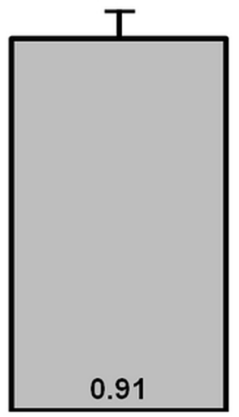

$A \beta 25 \mu M$

\section{P2X7 Activation, Chromatin Condensation and Caspase Activity}

Figure 2 shows a strong labeling of MIO-M1 cell membranes using a specific anti-P2X7 antibody (Fig. 2a, right) compared to the isotype control antibody (Fig. 2a, left).

Then, we analyzed P2X7 pore formation by the YO-PRO-1 assay. Fluorescence signal significantly increased $(\times 3.16, p<0.001)$ when MIO-M1 were incubated with A $\beta$ compared to negative control (Fig. $2 b$ ). When the A $\beta$-incubated MIO-M1 were preincubated with the P2X7 inhibitor, $\mathrm{BBG}$, the fluorescence signal significantly decreased $(\times 0.48, p<0.001)$ compared to $\mathrm{A} \beta$-incubated MIO-M1 without preincubation, confirming activation of $\mathrm{P} 2 \mathrm{X} 7$ by $\mathrm{A} \beta$. We also observed that a specific $\mathrm{P} 2 \mathrm{X} 7$ receptor activator, BzATP, increased $\mathrm{P} 2 \mathrm{X} 7$ pore formation, which confirms the specificity of the YO-PRO-1 assay to evaluate P2X7 activation. We also studied chromatin condensation, an irreversible early phase of apoptosis assessed by the Hoechst 33342 assay, because even no loss of cell viability at $48 \mathrm{~h}$ does not mean no apoptosis at 48 h. In Fig. 3, Hoechst 33342 fluorescence was significantly increased $(\times 2.11, p<0.001)$ in A $\beta$-treated MIO-M1 compared to negative control. Preincubation of A $\beta$-treated MIO-M1 with $\mathrm{BBG}$ totally inhibited chromatin condensation compared to A $\beta$-treated MIO-M1 without preincubation increased $(\times 0.53, p<0.001)$, indicating the central role of $\mathrm{P} 2 \mathrm{X} 7$ in the mediation 
a
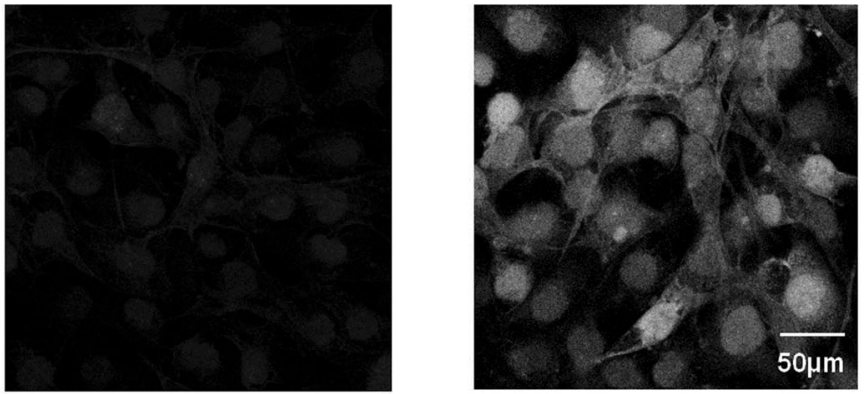

b
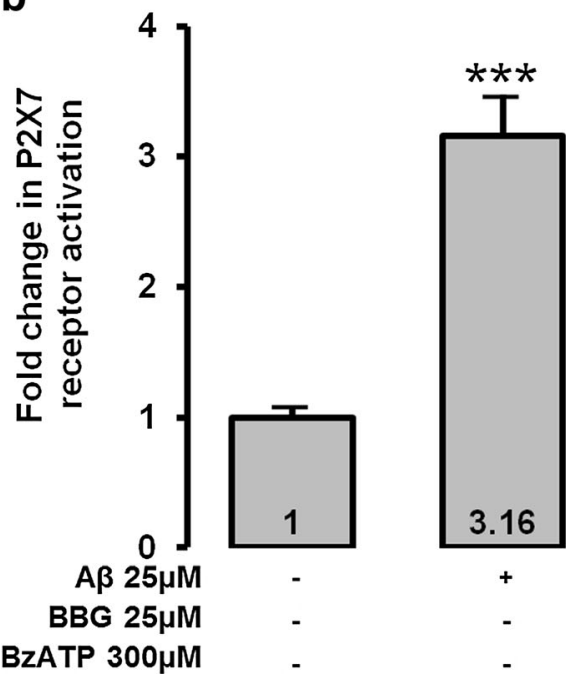

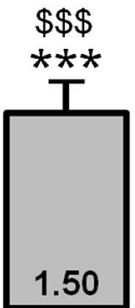

$+$

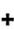

Fig. 2 Expression and activation of P2X7 receptor in MIO-M1 cells. a Isotype control (left) and P2X7 receptor labeling (right). Cells were observed using confocal microscopy $(200 \times)$. Pictures show mergence between nuclei and P2X7 staining. b P2X7 receptor activation using the YO-PRO-1 assay was evaluated after incubation of $25 \mu \mathrm{M} \mathrm{A} \beta$ for $48 \mathrm{~h}$. BBG at $25 \mu \mathrm{M}$ was used as a P2X7 receptor potent inhibitor and BzATP at $300 \mu \mathrm{M}$ was used as a positive control. ${ }^{* * *} p<0.001$ compared to negative control; $\$ \$ \$ p<0.001$ compared to $\mathrm{A} \beta$

Fig. 3 Chromatin condensation after incubation of $25 \mu \mathrm{M} \mathrm{A} \beta$ for 48 h. Chromatin condensation using Hoechst 33342 assay was evaluated after $A \beta$ incubation for $48 \mathrm{~h}$ in MIO-M1 retinal Müller cells. BBG at $25 \mu \mathrm{M}$ was used as a $\mathrm{P} 2 \mathrm{X} 7$ receptor potent inhibitor. $* * * p<0.001$ compared to negative control; $\$ \$ \$ p<0.001$ compared to $\mathrm{A} \beta$
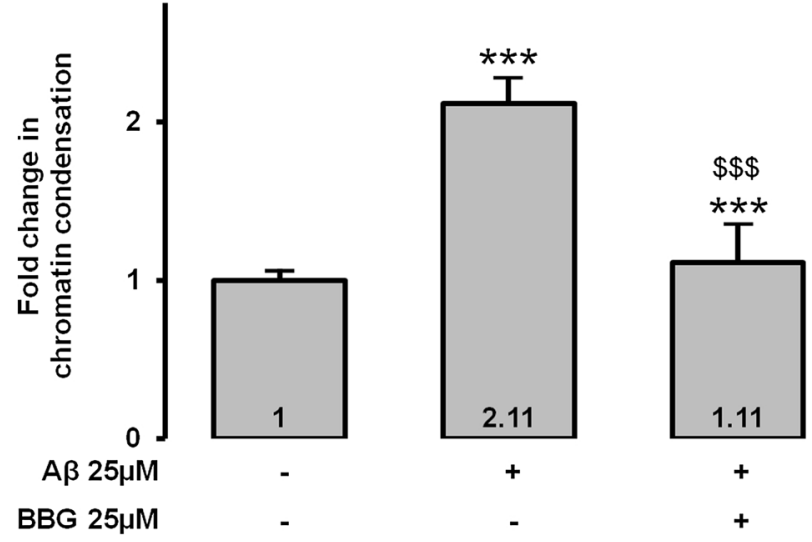
of A $\beta$-induced condensation of Müller cell chromatin. Finally, we evaluated caspase activation. We focused our attention on caspase 8 and caspase 3. No significant difference was observed between $A \beta$-treated MIO-M1 compared to negative control (Fig. 4a, b).

Altogether, these data indicated that $\mathrm{A} \beta$ first alters the chromatin state of Müller cells without inducing cell death at $48 \mathrm{~h}$.

\section{Protective Effects of EPA/DHA Associated in Fish Oil and BBG on A $\beta$-Cytotoxicity}

EPA and DHA have antioxidant and antiapoptotic roles in the retina, but their protective effects on Müller cells against $\mathrm{A} \beta$ remains undetermined. $\mathrm{P} 2 \mathrm{X} 7$ pore formation was significantly decreased $(\times 0.77, p<0.001)$ when $\mathrm{A} \beta$-treated MIO-M1 were preincubated with EPADHA fish oil compared to $A \beta$ alone, but the signal remains significantly higher than in the negative control (Fig. 5a), suggesting that $\mathrm{P} 2 \mathrm{X} 7$ receptor is a target for protective effects of EPA and DHA in A $\beta$-treated Müller cells. Preincubation of MIO-M1 with both EPA-DHA fish oil and BBG totally inhibited $\mathrm{P} 2 \mathrm{X} 7$ pore formation $(\times 0.33, p<0.001)$, meaning that $\mathrm{BBG}$ and EPA-DHA fish oil act synergically.

Analysis of chromatin condensation, an irreversible early phase of apoptosis assessed by the Hoechst 33342 assay, showed a significant decrease $(\times 0.78, p<0.001)$ in Hoechst 33342

Fig. 4 Caspase activation after incubation of $25 \mu \mathrm{M} \mathrm{A} \beta$ for $48 \mathrm{~h}$. Caspase 8 (a) and caspase 3 (b) activation were evaluated after $\mathrm{A} \beta$ incubation for $48 \mathrm{~h}$ in MIO-M1 retinal Müller cells
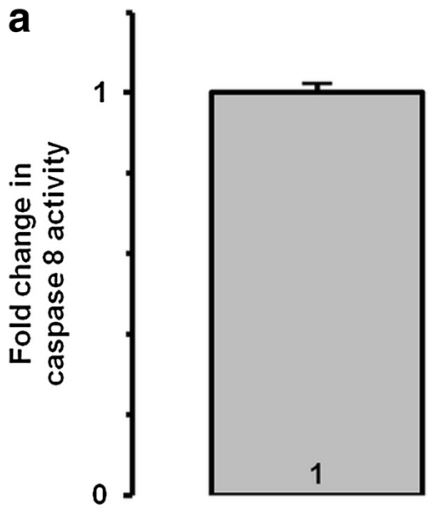

Negative control
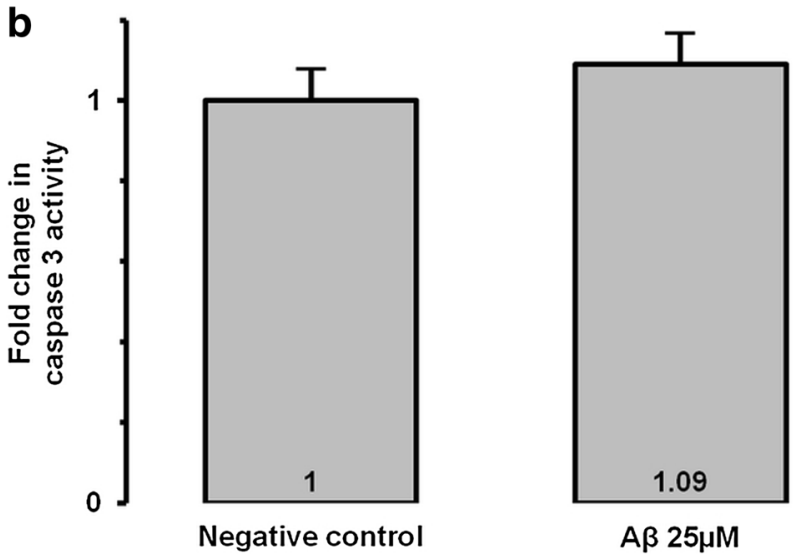
Fig. $5 \mathrm{~A} \beta$-induced apoptosis modulation with marine EPA and DHA lipid formulation. P2X7 receptor activation (a) and chromatin condensation (b) were evaluated after preincubation with fish EPA-DHA oil for $15 \mathrm{~min}$ and incubation of $25 \mu \mathrm{M} \mathrm{A} \beta$ for $48 \mathrm{~h}$ in MIO-M1 retinal Müller cells. BBG at $25 \mu \mathrm{M}$ was used as a $\mathrm{P} 2 \mathrm{X} 7$ receptor potent inhibitor. $* * * p<0.001$ compared to negative control; $\$ \$ \$ p<0.001$ compared to $\mathrm{A} \beta$ a

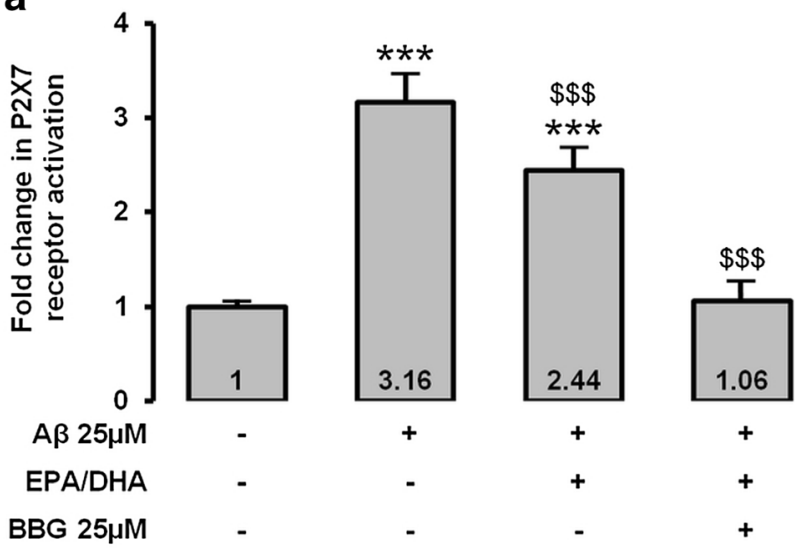

b

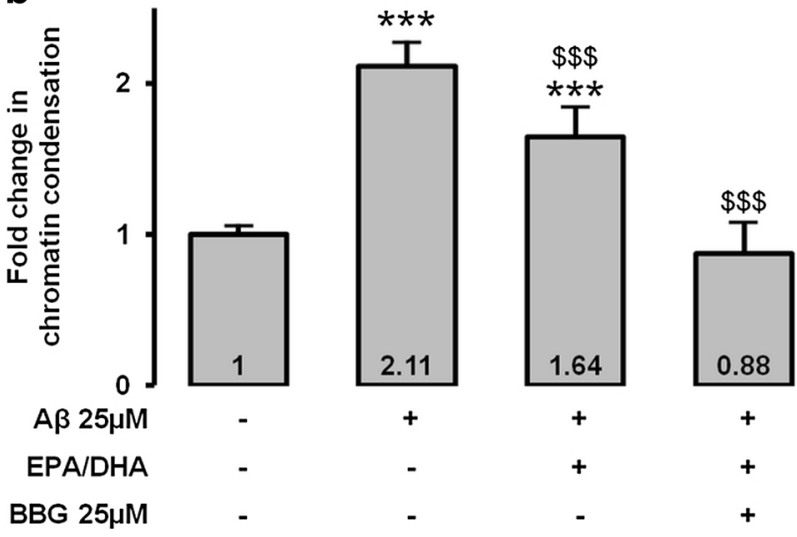

signal when the A $\beta$-treated MIO-M1 were preincubated with EPA-DHA fish oil compared to $\mathrm{A} \beta$-treated MIO-M1 without preincubation (Fig. 5b). Preincubation of A $\beta$-treated MIO-M1 with both EPA-DHA fish oil and BBG totally inhibited chromatin condensation compared to $\mathrm{A} \beta$-treated MIO-M1 with or without preincubation with EPA-DHA fish oil $(\times 0.42, p<0.001)$, confirming the $\mathrm{P} 2 \mathrm{X} 7$ receptor-mediated deleterious effects of $\mathrm{A} \beta$ and the potential protective role of EPA-DHA against these effects in Müller cells.

\section{Discussion}

Müller cells have been shown to be implicated in AMD [47, 48], and selective ablation of these cells led to photoreceptor apoptosis, blood-retinal barrier breakdown, and retinal neovascularization [49]. We studied the A $\beta$ effects on MIO-M1 cells to study the impact of this peptide involved in AMD pathogenesis on Müller cells. The lack of necrosis in the cells was determined by no increase in LDH levels and low levels of propidium iodide (data not shown). Apoptosis was revealed by higher levels of YO-PRO-1 and 
Hoechst 33342 fluorescence signals in A $\beta$-incubated cells than in control cells. Therefore, we report that oligomerized $A \beta$ induces apoptosis rather than necrosis on human retinal Müller cells (MIO-M1). P2X7 receptor is involved in oxidative stress, cell death, and inflammatory processes, all of which have been linked to AMD. A $\beta$-induced apoptosis appears to be $\mathrm{P} 2 \mathrm{X} 7$ cell death receptor-dependent and caspase-independent, but further investigations are needed to confirm that. We showed for the first time that P2X7 receptor activation plays a pivotal role in A $\beta$-induced apoptosis in Müller cells. Indeed, $\mathrm{P} 2 \mathrm{X} 7$ receptor inhibition using a specific antagonist (BBG) drastically decreased $A \beta$-induced apoptosis. Our results are in accordance with previous results that showed that P2X7 receptor blockade prevents photoreceptor cell apoptosis and confers neuroprotection in the brain of a rat model of Alzheimer's disease [50, 51]. However, the mechanism by which BBG acts remains to be deeper studied. In our model, P2X7 activation was not associated with extrinsic caspase 8 activation, as previously described $[52,53]$. Caspase 3 , which is involved both in the extrinsic and the intrinsic pathways, was not activated in our model, meaning that $\mathrm{A} \beta$ peptide induces $\mathrm{P} 2 \mathrm{X} 7$ activation leading to caspase-independent chromatin condensation in Müller cells. Apoptosisinducing factor (AIF) translocates from mitochondria to nuclei in a caspaseindependent fashion, leading to DNA fragmentation and chromatin condensation in cells undergoing apoptosis $[54,55]$. It was previously described that $A \beta$-induced cell death was associated with AIF translocation [56, 57].

The Age-Related Eye Disease Study 2 (AREDS2) was a multi-center, randomized trial designed to assess the effects of oral supplementation of DHA and EPA on the progression to advanced AMD. The results of this trial showed that addition of DHA and EPA as ethyl esters did not further reduce the risk of progression to advanced AMD. In our model, EPA and DHA as triglycerides in fish oil had preventive effects towards P2X7 cell death receptor-dependent apoptosis induced by $\mathrm{A} \beta$. We previously demonstrated that individual synthetic DHA or EPA are not as efficient as DHA and EPA associated in fish oils in the prevention of some ocular stresses [31]. Moreover, appropriate proportions of DHA/EPA seem to be needed to observe the most potent effect. Fatty acids contained in the lipid formulation we selected incorporate into retinal cell membranes [31], which can increase membrane fluidity and disrupt lipid rafts [58-61]. The activity of the numerous receptors expressed in lipid rafts, such as P2X7 receptor [62], may be modified. Effectively, we observed that $\mathrm{A} \beta$-induced $\mathrm{P} 2 \mathrm{X} 7$ receptor activation was reduced by our lipid formulation. This P2X7 cell death receptor blockade could occur through lipid raft disruption, as we previously showed that the EPA-DHA fish oil we used is able to modulate lipid rafts organization [63].

DHA (22:6 $\omega-3)$ is the precursor of EPA (20:5 $\omega-3)$, which is the omega-3 homologue of arachidonic acid (20:4 $\omega-6)$. Arachidonic acid is at the origin of pro-inflammatory mediators (prostaglandin E2); on the contrary, EPA is at the origin of anti-inflammatory mediators (prostaglandin E3) after metabolism by COX enzymes [64]. As we observed in a previous study, an increase in EPA can lead to a decrease in arachidonic acid in cell membranes and then to a decrease in the pro-inflammatory response [32]. It is thus suggested that the high content of EPA in our fish oil formulation could help in diminishing the inflammation associated to AMD. Fish EPA-DHA and BBG exerted synergic effects in the prevention of A $\beta$ damages in our model. As the potential application of BBG as a neuroprotective therapy has already been suggested [50], the mixture of fish EPA-DHA and BBG opens further new strategic therapeutics. 


\section{Conclusion}

For the first time, our study showed that $\mathrm{A} \beta$ seems to induce caspase-independent apoptosis through P2X7 receptor activation in human retinal cells. We showed that marine lipid formulation containing EPA and DHA as triglycerides, in combination with BBG, a specific $\mathrm{P} 2 \mathrm{X} 7$ receptor inhibitor, fully prevented $\mathrm{A} \beta$ cytotoxic effects in our model. Therefore, marine oils rich in EPA and DHA, in combination with a potent P2X7 receptor antagonist, could represent a promising efficient modulator of $\mathrm{A} \beta$ toxicity.

Acknowledgments The authors would like to thank Adebiopharm ER67, French Ministère de la Recherche and Agence Nationale de la Recherche (Paris, France) for their financial support. This study was a part of the ANRBLAN-0204 project coordinated by INSERM U598 unit (Professor Francine Behar-Cohen, Doctor Frédéric Mascarelli's team).

Open Access This article is distributed under the terms of the Creative Commons Attribution 4.0 International License (http://creativecommons.org/licenses/by/4.0/), which permits unrestricted use, distribution, and reproduction in any medium, provided you give appropriate credit to the original author(s) and the source, provide a link to the Creative Commons license, and indicate if changes were made.

\section{References}

1. Klein, R., Peto, T., Bird, A., \& Vannewkirk, M. R. (2004). The epidemiology of age-related macular degeneration. American Journal of Ophthalmology, 137, 486-495.

2. Chopdar, A., Chakravarthy, U., \& Verma, D. (2003). Age related macular degeneration. British Medical Journal, 326, 485-488.

3. Bringmann, A., Pannicke, T., Grosche, J., Francke, M., Wiedemann, P., Skatchkov, S. N., Osborne, N. N., \& Reichenbach, A. (2006). Muller cells in the healthy and diseased retina. Progress in Retinal and Eye Research, 25, 397-424.

4. Distler, C., \& Dreher, Z. (1996). Glia cells of the monkey retina.2. Muller cells. Vision Research, 36, 23812394.

5. Tout, S., Chanling, T., Hollander, H., \& Stone, J. (1993). The role of Muller cells in the formation of the blood-retinal barrier. Neuroscience, 55, 291-301.

6. Reichenbach, A., Wurm, A., Pannicke, T., Iandiev, I., Wiedemann, P., \& Bringmann, A. (2007). Muller cells as players in retinal degeneration and edema. Graefes Archive for Clinical and Experimental Ophthalmology, 245, 627-636.

7. Begum, R., Powner, M. B., Hudson, N., Hogg, C., \& Jeffery, G. (2013). Treatment with 670 nm light up regulates cytochrome $\mathrm{C}$ oxidase expression and reduces inflammation in an age-related macular degeneration model. PloS One, 8, e57828.

8. Marc, R. E., Jones, B. W., Watt, C. B., Vazquez-Chona, F., Vaughan, D. K., \& Organisciak, D. T. (2008). Extreme retinal remodeling triggered by light damage: implications for age related macular degeneration. Molecular Vision, 14, 782-806.

9. Shen, W., Fruttiger, M., Zhu, L., Chung, S. H., Barnett, N. L., Kirk, J. K., Lee, S., Coorey, N. J., Killingsworth, M., Sherman, L. S., \& Gillies, M. C. (2012). Conditional Muller cell ablation causes independent neuronal and vascular pathologies in a novel transgenic model. The Journal of Neuroscience : the Official Journal of the Society for Neuroscience, 32, 15715-15727.

10. Rutar, M., Natoli, R., \& Provis, J. M. (2012). Small interfering RNA-mediated suppression of Ccl2 in Muller cells attenuates microglial recruitment and photoreceptor death following retinal degeneration. Journal of Neuroinflammation, 9, 221.

11. Chong, E. W. T., Kreis, A. J., Wong, T. Y., Simpson, J. A., \& Guymer, R. H. (2008). Dietary omega-3 fatty acid and fish intake in the primary prevention of age-related macular degeneration - a systematic review and meta-analysis. Archives of Ophthalmology, 126, 826-833.

12. Fliesler, S. J., Maude, M. B., \& Anderson, R. E. (1983). Lipid composition of photoreceptor membranes from goldfish retinas. Biochimica et Biophysica Acta, 734, 144-152. 
13. Scott, B. L., \& Bazan, N. G. (1989). Membrane docosahexaenoate is supplied to the developing brain and retina by the liver. Proceedings of the National Academy of Sciences of the United States of America, 86, 2903-2907.

14. Shimazawa, M., Nakajimaa, Y., Mashima, Y., \& Hara, H. (2009). Docosahexaenoic acid (DHA) has neuroprotective effects against oxidative stress in retinal ganglion cells. Brain Research, 1251, $269-275$.

15. German, O. L., Insua, M., Gentili, C., Rotstein, N. P., \& Politi, L. E. (2006). Docosahexaenoic acid prevents apoptosis of retina photoreceptors by activating the ERK/MAPK pathway. Journal of Neurochemistry, 98, 1507-1520.

16. SanGiovanni, J. P., Chew, E. Y., Agron, E., Clemons, T. E., Ferris, F. L., Gensler, G., Lindblad, A. S., Milton, R. C., Seddon, J. M., Klein, R., Sperduto, R. D., \& Grp, A.-R. E. D. S. R. (2008). The relationship of dietary omega-3 long-chain polyunsaturated fatty acid intake with incident age-related macular degenerationAREDS report no. 23. Archives of Ophthalmology, 126, 1274-1279.

17. Anderson, D. H., Talaga, K. C., Rivest, A. J., Barron, E., Hageman, G. S., \& Johnson, L. V. (2004). Characterization of beta amyloid assemblies in drusen: the deposits associated with aging and age-related macular degeneration. Experimental Eye Research, 78, 243-256.

18. Dentchev, T., Milam, A. H., Lee, V. M. Y., Trojanowski, J. Q., \& Dunaief, J. L. (2003). Amyloid-beta is found in drusen from some age-related macular degeneration retinas, but not in drusen from normal retinas. Molecular Vision, 9, 184-190.

19. Isas, J. M., Luibl, V., Johnson, L. V., Kayed, R., Wetzel, R., Glabe, C. G., Langen, R., \& Chen, J. (2010). Soluble and mature amyloid fibrils in drusen deposits. Investigative Ophthalmology \& Visual Science, 51, 1304-1310.

20. Ning, A., Cui, J., To, E., Ashe, K. H., \& Matsubara, J. (2008). Amyloid-beta deposits lead to retinal degeneration in a mouse model of Alzheimer disease. Investigative Ophthalmology \& Visual Science, 49, 5136-5143.

21. Rat, P., Waks, A., Dutot, M., De Moucheron, B., Laprevote, O. and Warnet, J. (2011) BetaAmyloid induces toxic degenerative pathways on human retinal cells with P2X7 cell death receptor activation: Role in Age-Related Macular Degeneration (AMD). Toxicology letters, pp. S240-S240. Eurotox, Paris, France.

22. Wakx, A., Rat, P., De Moucheron, B., Dutot, M. and Laprévote, O. (2011) Evaluation and modulation of toxic degenerative pathways induced by beta-amyloid on retinal cells: role of P2X7 cell death receptor. Alzheimer Association International Conference on Alzheimer Disease. Paris.

23. Bruban, J., Glotin, A. L., Dinet, V., Chalour, N., Sennlaub, F., Jonet, L., An, N., Faussat, A. M., \& Mascarelli, F. (2009). Amyloid-beta(1-42) alters structure and function of retinal pigmented epithelial cells. Aging Cell, 8, 162-177.

24. Kurji, K. H., Cui, J. Z., Lin, T., Harriman, D., Prasad, S. S., Kojic, L., \& Matsubara, J. A. (2010). Microarray analysis identifies changes in inflammatory gene expression in response to amyloid-beta stimulation of cultured human retinal pigment epithelial cells. Investigative Ophthalmology \& Visual Science, 51, 11511163.

25. Surprenant, A., Rassendren, F., Kawashima, E., North, R. A., \& Buell, G. (1996). The cytolytic P2Z receptor for extracellular ATP identified as a P2X receptor (P2X7). Science, 272, 735-738.

26. Guha, S., Baltazar, G. C., Coffey, E. E., Tu, L. A., Lim, J. C., Beckel, J. M., Patel, S., Eysteinsson, T., Lu, W., O’Brien-Jenkins, A., Laties, A. M., \& Mitchell, C. H. (2013). Lysosomal alkalinization, lipid oxidation, and reduced phagosome clearance triggered by activation of the $\mathrm{P} 2 \mathrm{X} 7$ receptor. FASEB Journal : Official Publication of the Federation of American Societies for Experimental Biology, 27, 4500-4509.

27. Nussenblatt, R. B., Lee, R. W., Chew, E., Wei, L., Liu, B., Sen, H. N., Dick, A. D., \& Ferris, F. L. (2014). Immune responses in age-related macular degeneration and a possible long-term therapeutic strategy for prevention. American Journal of Ophthalmology, 158(5-11), e12.

28. Parmeggiani, F., Sorrentino, F. S., Romano, M. R., Costagliola, C., Semeraro, F., Incorvaia, C., D’Angelo, S., Perri, P., De Nadai, K., Bonomo Roversi, E., Franceschelli, P., Sebastiani, A., \& Rubini, M. (2013). Mechanism of inflammation in age-related macular degeneration: an up-to-date on genetic landmarks. Mediators of Inflammation, 2013, 435607.

29. Gu, B. J., Baird, P. N., Vessey, K. A., Skarratt, K. K., Fletcher, E. L., Fuller, S. J., Richardson, A. J., Guymer, R. H., \& Wiley, J. S. (2013). A rare functional haplotype of the P2RX4 and P2RX7 genes leads to loss of innate phagocytosis and confers increased risk of age-related macular degeneration. Faseb Journal, 27, 1479-1487.

30. Notomi, S., Hisatomi, T., Kanemaru, T., Takeda, A., Ikeda, Y., Enaida, H., Kroemer, G., \& Ishibashi, T. (2011). Critical involvement of extracellular ATP acting on P2RX7 purinergic receptors in photoreceptor cell death. The American Journal of Pathology, 179, 2798-2809. 
31. Dutot, M., de la Tourrette, V., Fagon, R. and Rat, P. (2011) New approach to modulate retinal cellular toxic effects of high glucose using marine epa and dha. Nutrition \& metabolism, 8.

32. Dutot, M., Liang, H., Martin, C., Rousseau, D., Grynberg, A., Warnet, J. M. and Rat, P. (2009) Per os administered refined olive oil and marine PUFA-rich oils reach the cornea: possible role on oxidative stress through caveolin-1 modulation. Nutrition \& metabolism, 6.

33. Jiang, L. H., Mackenzie, A. B., North, R. A., \& Surprenant, A. (2000). Brilliant blue G selectively blocks ATP-gated rat P2X(7) receptors. Molecular Pharmacology, 58, 82-88.

34. Bruban, J., Glotin, A. L., Dinet, V., Chalour, N., Sennlaub, F., Jonet, L., An, N., Faussat, A. M., \& Mascarelli, F. (2009). Amyloid-beta(1-42) alters structure and function of retinal pigmented epithelial cells. Aging Cell, 8, 162-177.

35. Limb, G. A., Salt, T. E., Munro, P. M. G., Moss, S. E., \& Khaw, P. T. (2002). In vitro characterization of a spontaneously immortalized human Muller cell line (MIO-M1). Investigative Ophthalmology \& Visual Science, 43, 864-869.

36. Bull, N. D., Limb, G. A., \& Martin, K. R. (2008). Human Muller stem cell (MIO-M1) transplantation in a rat model of glaucoma: survival, differentiation, and integration. Investigative Ophthalmology \& Visual Science, 49, 3449-3456.

37. Said, T., Dutot, M., Christon, R., Beaudeux, J. L., Martin, C., Warnet, J. M., \& Rat, P. (2007). Benefits and side effects of different vegetable oil vectors on apoptosis, oxidative stress, and P2X7 cell death receptor activation. Investigative Ophthalmology \& Visual Science, 48, 5000-5006.

38. Kawahara, S., Hata, Y., Miura, M., Kita, T., Sengoku, A., Nakao, S., Mochizuki, Y., Enaida, H., Ueno, A., Hafezi-Moghadam, A., \& Ishibashi, T. (2007). Intracellular events in retinal glial cells exposed to ICG and BBG. Investigative Ophthalmology \& Visual Science, 48, 4426-4432.

39. O'Brien, J., Wilson, I., Orton, T., \& Pognan, F. (2000). Investigation of the Alamar Blue (resazurin) fluorescent dye for the assessment of mammalian cell cytotoxicity. European Journal of Biochemistry, 267, 5421-5426.

40. Fischer, A. B. (1975). Gentamicin as a bactericidal antibiotic in tissue-culture. Medical Microbiology and Immunology, 161, 23-39.

41. Idziorek, T., Estaquier, J., De Bels, F., \& Ameisen, J. C. (1995). YOPRO-1 permits cytofluorometric analysis of programmed cell death (apoptosis) without interfering with cell viability. Journal of Immunological Methods, 185, 249-258.

42. Dutot, M., Pouzaud, F., Larosche, I., Brignole-Baudouin, F., Warnet, J. M., \& Rat, P. (2006). Fluoroquinolone eye drop-induced cytotoxicity: role of preservative in P2X7 cell death receptor activation and apoptosis. Investigative Ophthalmology \& Visual Science, 47, 2812-2819.

43. Pauloin, T., Dutot, M., Warnet, J. M., \& Rat, P. (2008). In vitro modulation of preservative toxicity: high molecular weight hyaluronan decreases apoptosis and oxidative stress induced by benzalkonium chloride. European Journal of Pharmaceutical Sciences, 34, 263-273.

44. Dutot, M., Paillet, H., Chaumeil, C., Warnet, J. M., \& Rat, P. (2009). Severe ocular infections with contact lens: role of multipurpose solutions. Eye (London, England), 23, 470-476.

45. Dutot, M., Warnet, J. M., Baudouin, C., \& Rat, P. (2008). Cytotoxicity of contact lens multipurpose solutions: role of oxidative stress, mitochondrial activity and P2X7 cell death receptor activation. European Journal of Pharmaceutical Sciences, 33, 138-145.

46. Dutot, M., Liang, H., Pauloin, T., Brignole-Baudouin, F., Baudouin, C., Warnet, J. M., \& Rat, P. (2008). Effects of toxic cellular stresses and divalent cations on the human P2X7 cell death receptor. Molecular Vision, 14, 889-897.

47. Vessey, K. A., Greferath, U., Jobling, A. I., Phipps, J. A., Ho, T., Waugh, M., \& Fletcher, E. L. (2012). Ccl2/ $\mathrm{Cx} 3 \mathrm{cr} 1$ knockout mice have inner retinal dysfunction but are not an accelerated model of AMD. Investigative Ophthalmology \& Visual Science, 53, 7833-7846.

48. Cuenca, N., Fernandez-Sanchez, L., Campello, L., Maneu, V., De la Villa, P., Lax, P. and Pinilla, I. (2014) Cellular responses following retinal injuries and therapeutic approaches for neurodegenerative diseases. Progress in Retinal and Eye Research.

49. Shen, W., Lee, S. R., Araujo, J., Chung, S. H., Zhu, L., \& Gillies, M. C. (2014). Effect of glucocorticoids on neuronal and vascular pathology in a transgenic model of selective Muller cell ablation. Glia, 62, 1110-1124.

50. Notomi, S., Hisatomi, T., Murakami, Y., Terasaki, H., Sonoda, S., Asato, R., Takeda, A., Ikeda, Y., Enaida, H., Sakamoto, T., \& Ishibashi, T. (2013). Dynamic increase in extracellular ATP accelerates photoreceptor cell apoptosis via ligation of P2RX7 in subretinal hemorrhage. PloS One, 8, e53338.

51. Ryu, J. K., \& McLarnon, J. G. (2008). Block of purinergic P2X(7) receptor is neuroprotective in an animal model of Alzheimer's disease. Neuroreport, 19, 1715-1719.

52. Wang, Q., Wang, L., Feng, Y. H., Li, X., Zeng, R., \& Gorodeski, G. I. (2004). P2X7 receptor-mediated apoptosis of human cervical epithelial cells. American Journal of Physiology - Cellular Physiology, 287, C1349-1358. 
53. Fu, W., McCormick, T., Qi, X., Luo, L., Zhou, L., Li, X., Wang, B. C., Gibbons, H. E., Abdul-Karim, F. W., \& Gorodeski, G. I. (2009). Activation of P2X(7)-mediated apoptosis Inhibits DMBA/TPA-induced formation of skin papillomas and cancer in mice. BMC Cancer, 9, 114.

54. Susin, S. A., Lorenzo, H. K., Zamzami, N., Marzo, I., Snow, B. E., Brothers, G. M., Mangion, J., Jacotot, E., Costantini, P., Loeffler, M., Larochette, N., Goodlett, D. R., Aebersold, R., Siderovski, D. P., Penninger, J. M., \& Kroemer, G. (1999). Molecular characterization of mitochondrial apoptosis-inducing factor. Nature, $397,441-446$.

55. Daugas, E., Nochy, D., Ravagnan, L., Loeffler, M., Susin, S. A., Zamzami, N., \& Kroemer, G. (2000). Apoptosis-inducing factor (AIF): a ubiquitous mitochondrial oxidoreductase involved in apoptosis. FEBS Letters, 476, 118-123.

56. Meng, P., Yoshida, H., Tanji, K., Matsumiya, T., Xing, F., Hayakari, R., Wang, L., Tsuruga, K., Tanaka, H., Mimura, J., Kosaka, K., Itoh, K., Takahashi, I., Kawaguchi, S., \& Imaizumi, T. (2015). Carnosic acid attenuates apoptosis induced by amyloid-beta 1-42 or 1-43 in SH-SY5Y human neuroblastoma cells. Neuroscience Research, 94, 1-9.

57. Movsesyan, V. A., Stoica, B. A., \& Faden, A. I. (2004). MGLuR5 activation reduces beta-amyloid-induced cell death in primary neuronal cultures and attenuates translocation of cytochrome $\mathrm{c}$ and apoptosis-inducing factor. Journal of Neurochemistry, 89, 1528-1536.

58. Yang, X., Sheng, W., Sun, G. Y., \& Lee, J. C. (2011). Effects of fatty acid unsaturation numbers on membrane fluidity and alpha-secretase-dependent amyloid precursor protein processing. Neurochemistry International, 58, 321-329.

59. Rockett, B. D., Franklin, A., Harris, M., Teague, H., Rockett, A., \& Shaikh, S. R. (2011). Membrane raft organization is more sensitive to disruption by (n-3) PUFA than nonraft organization in EL4 and B cells. The Journal of Nutrition, 141, 1041-1048.

60. Ravacci, G. R., Brentani, M. M., Tortelli, T., Jr., Torrinhas, R. S., Saldanha, T., Torres, E. A., \& Waitzberg, D. L. (2013). Lipid raft disruption by docosahexaenoic acid induces apoptosis in transformed human mammary luminal epithelial cells harboring HER-2 overexpression. The Journal of Nutritional Biochemistry, 24, 505515.

61. Chen, W., Jump, D. B., Esselman, W. J., \& Busik, J. V. (2007). Inhibition of cytokine signaling in human retinal endothelial cells through modification of caveolae/lipid rafts by docosahexaenoic acid. Investigative Ophthalmology \& Visual Science, 48, 18-26.

62. Barth, K., Weinhold, K., Guenther, A., Young, M. T., Schnittler, H., \& Kasper, M. (2007). Caveolin-1 influences P2X7 receptor expression and localization in mouse lung alveolar epithelial cells. The FEBS Journal, 274, 3021-3033.

63. Dutot, M., de la Tourrette, V., Fagon, R., \& Rat, P. (2011). New approach to modulate retinal cellular toxic effects of high glucose using marine epa and dha. Nutrition \& Metabolism, 8, 39.

64. Bagga, D., Wang, L., Farias-Eisner, R., Glaspy, J. A., \& Reddy, S. T. (2003). Differential effects of prostaglandin derived from omega-6 and omega-3 polyunsaturated fatty acids on COX-2 expression and IL-6 secretion. Proceedings of the National Academy of Sciences of the United States of America, 100, 17511756. 